UDC 556.314:550.4

Vasyl Grygorovych Suyarko,

Doctor of Science (Geology and Mineralogy), Professor,

Chair of Mineralogy, Petrography and Minerals, V. N.Karazin Kharkiv National University,

Svobody sq., 4, Kharkiv, 61022, Ukraine,

e-mail: vgsuyarko@gmail.com, https://orcid.org/0000-0002-3693-4767;

Liliya Volodymyrivna Ishchenko,

PhD student, Lecturer,

Chair of Mineralogy, Petrography and Minerals, V.N.Karazin Kharkiv National University, lvishchenko23@gmail.com, https://orcid.org/0000-0002-0848-368X;

Olga Volodymyrivna Gavrilyuk,

$\mathrm{PhD}$ student, Lecturer,

Department of Soil Mechanics, Foundations and Engineering Geology,

O. M. Beketov National University of Urban Economy in Kharkiv,

e-mail: gavrilyk.o.v@gmail.com, https://orcid.org/0000-0002-7057-2499

\title{
FLUID REGIME AND ORE WATER OF BITUMO-HYDROTHERMAL MINERAL ASSOCIATIONS IN THE CONDITIONS OF WESTERN DONETSK GRABEN
}

В.Г. Суярко, Л.В. Іщенко, О.В. Гаврилюк. ФЛЮЇДНИЙ РЕЖИМ ТА ОРЕОЛЬНІ ВОДИ БІТУМОГІДРОТЕРМАЛЬНИХ МІНЕРАЛЬНИХ АСОЦІАЦИЙ В УМОВАХ ЗАХІДНО-ДОНЕЦЬКОГО ГРАБЕНУ. ФорМУваННЯ бітумо-гідротермальних мінеральних асочіачій, під якими автори розуміють просторово і генетично обумовлене спільне знаходження у гірських породах гідротермальних мінералів та природних бітумів, характеризуються специифічним флюїдним режимом. У породах Західно-Донецького грабену гідротермаліти, що представлені рудними та нерудними мінералами, асоціюють з твердими бітумами - природними сполуками, щь складаються з високомолекулярних вуглеводнів та гетероатомних молекул різного виду і походження. Це явище спостерігається у породах антиклінальних структур з якими пов'язані відомі рудні поля ртутної та поліметалічної спеціалізації - Микитівське, Дружківсько-Костянтинівське та Слов'янське.

Для цих поліхронних гідротермальних систем вирішальне значення у виникненні бітумо-гідротермальних асоиіацій мала ларамійська фаза альпійського тектогенезу.

Структурно ці системи приурочені до тектоногенних зон розущільнення у склепінних частинах антикліналей. Ореольні води, що тут формуються, уміщують як хімічні елементи та сполуки, запозичені з порід, мінералів та бітумів, так $i$ ті, щзо надходять з підкорових глибин у флюїдних потоках.

Геохімічні аномалї̈ (літо-, гідро- та газо-) супроводжуються геотермічними і утворюються на ділянках сучасної тектонічної активізації антиклінальних структур, щฺо свідчить про сучасний (постгідротермальний) етап розвитку гідротермальних систем у регіоні.

Ключові слова: флюїдний режим, бітумо-гідротермальна асочіачія, Західно-Донецький грабен, тектонічний розлом, тепломасоперенесення, ореольні води, гази, тектонічна фаза.

В.Г. Суярко, Л.В. Іщенко, О.В. Гаврилюк. ФЛЮИДНЫЙ РЕЖИМ И ОРЕОЛЬНЫЙ ВОДЫ БИТУМО ГИДРОТЕРМАЛЬНЫХ МИНЕРАЛЬНЫХ АСОЦИАЦИЙ В УСЛОВИЯХ ЗАПАДНО-ДОНЕЦКОГО ГРАБЕНА. ФОРМИрование битумо-гидротермальных минеральных ассоциаций под которыми авторы понимают пространственно и генетически обусловленное совместное нахождение в горных породах гидротермальных минералов и природных битумов, характеризуются специфическим флюидным режимом. В породах Западно-Донецкого грабена гидротермалиты, которые представленные рудными и нерудными минералами, ассоциируют с твердыми битумами - природными соединениями, что состоят из высокомолекулярных углеводородов и гетероатомных молекул разного вида и происхождения. Это явление наблюдается в породах антиклинальных структур с которыми связаны известные рудные поля ртутной и полиметаллической специализации - Никитовское, Дружкковско-Константиновское и Славянское.

Для этих полихронных гидротермальных систем решающее значение в возникновении битумо-гидротермальных ассоииачий имела ларамийская фаза альпийского тектогенеза.

Структурно эти системы приурочены к тектоническим зонам разуплотнения пород в сводовых частях антиклиналей. Ореольные воды здесь формируются как за счет химических элементов и соединений, которые заимствованные из пород, минералов и битумов, так и за счет, флюидных потоков, которые поступают из подкоровых глубин. Геохимические аномалии (лито-, гидро- и газо-) сопровождаются геотермическими и образуются на участках современной тектонической активности антиклинальных структур, что свидетельствует о современном (постгидротермальном) этапе развития гидротермальных систем в регионе.

Ключевые слова: флюидный режим, битумо-гидротермальная ассоииачия, Западно-Донецкий грабен, тектонический разлом, тепломассоперенос, ореольные воды, газы, тектоническая фаза.

Problem formulation. By the term "bitumenhydrothermal mineral association," the authors understand the spatially and genetically determined joint location of hydrothermal minerals and natural bitumen in rocks. In this case, "natural bitumen" is a natural hydrocarbon compound of a solid, viscous and viscous-liquid consistency consisting of high molecular hydrocarbons and heteroatomic (oxygen, sulfur, nitrogen and metal-containing) compounds having structural viscosity and non-Newtonian fluids [25]. Ore water of such associations is characterized by certain geochemical specifics.

Hydrothermal mineralization in the rocks of the Western Donetsk graben, which is the eastern part of 
the Dnieper-Donetsk paleorift, is often found together with solid bitumen. This phenomenon is established in various ore fields of the region. Among them are Nikitovskoe, Druzhkivsko-Konstantinovsky, Slovyanskoye ore fields and numerous orodimensions of hydrothermal mineralization in rocks. All of them are confined to different types of anticlinal structures.

On the other hand, in the rocks of most of the oil-and-gas bearing structures known in the Western Donetsk graben (and not only here), there is both ore hydrothermal mineralization and non-ore. Such a pattern, in our opinion, is not only due to the joint ways of migration, but also, possibly, to the joint sources of generation of hydrothermal minerals and hydrocarbons. Considering this issue, one should proceed from the fact that the energy basis for the formation of hydrothermal mineralization, as well as the accumulation of hydrocarbons in the earth's crust is the fluid heat-and-mass transfer. Heat flows formed in the mantle, carry out ascending unloading in the zones of deep faults and, saturating with mineral matter, carry huge masses of geological matter from hydrothermal mineral-forming solutions to gasliquid fluids, an essential component of which are hydrocarbons. In addition, by capturing the substance of rocks in the course of its movement, these endogenous streams are unloaded in areas of the removal of geostatic pressure within the limits of anticlinal folds that are increasing in the present time [2,5,20,33,37].

The indicated processes are caused mainly by three factors: features of geological development of the region; its structural structure and the modern level of tectonic activity of the region. All other factors (geophysical, hydrogeological, lithological, geochemical, etc.) are of secondary importance.

Analysis of the latest research and publications. The problem of the fluid regime of hydrothermal processes involving hydrocarbon compounds has long been the subject of discussion in scientific geological circles around the world.

In the early stages, as well as now, it is often considered in the context of two opposing paradigms - the organic and inorganic origin of hydrocarbons. This, on the one hand, makes it rather interesting and ambiguous, and on the other - requires specific scientific facts and research results.

In frequent cases, there is a joint finding of solid bitumen, naphtides, petroleum, methane and its homologues within hydrothermal ore fields. This phenomenon is observed on different continents, mainly in areas with a young Meso-Cenozoic tectonic activity, which is the result of modern heat-andmass transfer in the earth's crust, the most intense foci of which are concentrated on the fluid-dynamic open areas of zones of deep faults $[6,19,25,32]$.
Among the researchers who studied this problem somehow or another, there are the well-known Ukrainian (G. Dolenko, V. Porfiriev, I. Chebanenko, M. Pavlyuk, O. Lukin, E. Chekalyuk, V. Gavrish, L. Dobryansky), Russian (P. Kropotkin, M. Kudryavtsev, N. Ozerova, N. Beskrovny, J. Pikovsky), american (D. White, A. James, M. Cox, E. Bailey, R. Carson) and many other scientists from different countries of the world.

Often low- and medium-temperature mercury mineralization is associated with bitumen, petroleum and hydrocarbon gases. Hydrothermal mineralization and bituminous materials are widely represented in Meso-Cenozoic folded and volcanic structures of the Pacific rim [21]. Spatial connections of hydrothermal mineralization and hydrocarbon compounds are found in the Ukrainian Carpathians and the Crimea, the Czech Sudeten and the Spanish Pyrenees, the Central Asian structures of Tien Shan and Pamir, in North America and Africa, in Siberia and New Zealand. This phenomenon is observed on different continents, which makes it, in fact, general- planetary $[3,5,6,10,12,19,32,38]$.

Regional studies have established bitumenhydrothermal mineral associations in the region. In addition to the Nikitovsky, DruzhkivskyKonstantinovsky and Slavic ore fields, they were found on Bilyaivsky, Spivakivsky, Petrovsky, Izyumsky and other anticlinal structures [10,12].

The development and improvement of the laboratory and experimental base of geological science with the involvement of such modern research methods as isotopic and mass spectrometric analyzes reproduces the basic parameters of the fluid regime, in which hydrocarbons participate in hydrothermal mineral formation $[2,5,8,33,34]$. This, in turn, makes it possible to quite realistically define the formation of bitumen-hydrothermal mineral associations in rocks and the formation of halo waters around them $[13,25,27,38$,$] .$

To date, considerable volumes of field and experimental information have been accumulated on the modeling of hydrothermal processes of mineral formation and oil and gas accumulation in the upper part of the earth's crust due to mantle exhalations $[2,17,18,20]$.

A few studies are devoted to bitumen hydrothermal mineral associations in the rocks of the Western Donetsk graben associated with the works of V. Shumlyanskii, A. Gorovy, V. Skarzhinsky, V. Suyarko, K. Bezruk, L. Ishchenko [3,14,25,34].

Particular attention should be paid to the works that determine the thermodynamics of the deep processes of heat-and-mass transfer both in hydrothermal ore fields [27,37] and in zones of deep oil and gas accumulation [2,20, 30]. Particular attention should be paid to the development of models of formation of halo waters in the hydrothermal ore fields 
of the region at the expense of the endogenous and exogenous fluid-dynamical factors and processes $[13,14,25,27,30]$.

Selection of previously unsolved parts of the general problem. Resolving the problem of hydrocarbon participation in the hydrothermal process is of a general nature and needs to be clarified and detailed for different geological regions. This, above all, is determined by the conditions that determine the formation of bitumen-hydrothermal mineral associations in erupted rocks. Among the unresolved separate problems of this problem is the formation of a fluid regime of hydrothermal process with the participation of hydrocarbons in the conditions of the Dnieper-Donetsk paleorift, and in particular, Western Donetsk graben.

Formulating the purpose of the article. Investigation of the features of the fluid regime and the participation of hydrocarbons in a hydrothermal process in the conditions of the Western Donetsk graben (Dniprovsk-Donetsk paleorift).

Presenting main material. Formation and further geological development of the Dnieper-Donetsk paleorift (including the territory of research) are associated with the periods of tectonic activation, accompanied by the formation of new and rebuilding existing folded and burst structures, in sedimentary rocks of which hydrothermal minerals deposited, that are spatially-genetically connected with bitumen.

Tectonic disturbances, different in order, direction and amplitudes, several of which reach the mantle, were and are now the main channels of heat-andmass transfer. It is with them that the upstream flows of thermal crust-mantle fluids, deep water and hydrocarbon migration are connected [16,18,37]. For the last tectonic channels, in spite of the traditional ideas, are, in our opinion, not only the underlying but also the distributive ones. At the same time, under favorable structural-tectonic and lithologycallyfacies conditions, discontinuous tectonic disturbances with signs of hydrothermal activity can be the main factor in the formation of hydrocarbon traps in deep (more than 4-6 km) Paleozoic horizons, as well as in the upper part of the geological section [28]. This, in our opinion, is due to the development of powerful dissolution zones around them.

Within the active sections of faults in various geological epochs of the region, there were tectonic movements, the result of which were magmatism, hydrothermal activity and conglomeration of hydrocarbon accumulations. The authors associate the activation of fracturing structures and the intensification of heat-and-mass transfer processes with the Alpine tectogenesis, the result of which were neotectonic geodynamic stresses, manifestation of which is the geothermal field tensity, fluid mass transfer and anomalies of high reservoir pressure in the rocks, as well as gas and hydrogeochemical anomalies of methane and its homologues, which are direct indicators of oil and gas pressence [28].

Modern heat-and-mass transfers on the territory of research are established within the limits of ancient polychronic hydrothermal systems, the most active resumption of which occurred in the Laramie phase of alpine tectogenesis. Here there is an ascending unloading of alkaline ( $\mathrm{pH} 7,8-9,2)$, chloridesodium and chloride-hydrocarbonate-sodium waters with high (sometimes with very low) mineralization and abnormally high concentrations of endogenous chemical elements ( $\mathrm{Hg}, \mathrm{B}, \mathrm{Li}, \mathrm{Rb}, \mathrm{Cs}, \mathrm{I}, \mathrm{F}, \mathrm{Br}$ As etc.). In the dissolved or free state, the gases $-\mathrm{CO}_{2}$, $\mathrm{CH}_{4}, \mathrm{~N}_{2}$, etc., are fixed here, among which the metamorphogenic mantle occupy a prominent place $\mathrm{H}_{2}, \mathrm{Ag}$, Ne, steam $\mathrm{Hg}$. For the most part, such cells spatially coincide with the sections of both modern tectonic activity and high tensity thermal field. Sometimes they are accompanied by geophysical anomalies of different nature. Such centers of unloading of endogenous fluids that are abnormal in chemical composition, heat flow, groundwater and deep-formed gases are detected in the zones of the Central Donetsk, Korul'sko-Dronovsky, Mushketovsky-Persianovsky, Krasnoritsky, Maryovskogo and many other faults, the existence of which is associated with processes that occur under the earth's crust $[8,18,27]$.

At a depth of up to $1000 \mathrm{~m}$, gases are dominated by carbon dioxide, the concentration of which is 2 times higher than the background, and methane spontaneously released during well drilling within the limits of ancient hydrothermal systems controlled by regional faults $[15,16]$. Sometimes, the temperature of the waters of the Paleozoic and Mesozoic deposits even at depths up to 0-300 m reaches $23^{\circ}-27^{\circ} \mathrm{C}[25,28]$ at the background values of $10^{\circ}$ $12^{\circ} \mathrm{C}$. Such hydrogeotermic anomalies are found within the limits of anticlinal structures with hydrothermal mineralization and manifestations of oil and gas, controlled by deep faults: on Main (Horlivska) (up to $18^{\circ} \mathrm{C}$ ), Druzhkivsky-Konstantinovsky (up to $19^{\circ} \mathrm{C}$ ), Slavyansk (up to $20^{\circ} \mathrm{C}$ ). Svyatohirskaya (up to $27^{\circ} \mathrm{C}$ ), Korul (up to $22^{\circ} \mathrm{C}$ ) anticlines and some other structures of the region. The excess by the average abnormal temperatures of groundwater of similar proportions in the rocks confirms the version that the deep waters of faulty structures are the main factor of heat-and-mass transfer in the upper zones of the earth's crust [4].

Experimental studies have established that heatand-mass transfer in the deep areas of the earth's crust occurs at the expense of gaseous fluids, and in the upper part of it, it is controlled by the circulation of sodium chloride waters and brines containing components of high molecular weight hydrocarbon compounds. The composition of these compounds 
(molecules) may include nitrogen, sulfur, oxygen, halogens (fluorine, iodine, bromine), as well as metals in the complex forming so-called asphaltsmearing substances. Generally, more than 900 hydrocarbon compounds of paraffin, naphthenic and aromatic series contain all of these microcomponents [24]. Among them, of particular interest from the genetic point of view, are heavy metals $(\mathrm{Ni}, \mathrm{Cr}$, $\mathrm{V}, \mathrm{W}, \mathrm{Fe}, \mathrm{Hg}$, etc.), which are almost always present not only in oil, but also in hydrocarbon gases $[5,16,24]$. They are the specific genetic markers of hydrocarbons. Taking into account the natural thermodynamic conditions, extracting heavy metals from crystalline rocks is possible only at such temperatures and pressures, when the oil in its usual form, cannot exist as a crystalline mineral $[31,33,34,37]$.

In the study of hydrogeochemical and gasogeochemical anomalies, one of the most important issues is the genesis of their components. The answer to it can be considered in two aspects: 1) the origin of the main components of groundwater and gases; 2) genesis of microelements of water and dissolved and free gases [28].

The analysis of the isotopic composition of hydrogen and oxygen of groundwater in the zones of deep faults in the region has confirmed that they are mainly (95-97\%) are hidden seawater diluted in the sedimentation pool by infiltration water [7]. This suggests that only 5-7\% of groundwater of fault zones can be "juvenile waters", which are highly diluted with vadose waters, but are actively involved in the formation of hydrothermal and hydrocarbon deposits and their ore water. However, in the process of considering the origin of water, it is necessary to take into account the isotopic ratio of $\mathrm{O}_{2}, \mathrm{H}_{2}$, and to study the isotopes of dissolved chemical elements in them. The content of the latter in fault zone waters depends on the temperature, chemical composition and velocity of the fluids - factors that determine the solubility of the isotopes, the duration of contact with the rocks and the vadose waters. Among the chemical elements, the isotopes of carbon, uranium, radium, radon, argon, helium are of fundamental importance for genetic diagnostics of fluid and solid forms of geological matter.

The most actively entering the water of the deep faults of the Dnieper-Donetsk aulacogene are carbon dioxide $\left(\mathrm{CO}_{2}\right)$ and methane $\left(\mathrm{CH}_{4}\right)$. The latter is likely to be a product of degassing the mantle, as well as metamorphism of sedimentary rocks. In mantle carbon dioxide, the content of heavy nuclide $\delta^{13} \mathrm{C}$ is in the range of $6-13 \%$ for an average value of $7 \%$. This isotopic composition also has methane, which can be formed in the mantle together with $\mathrm{CO}_{2}$ during the interaction of carbon with water $[2,7,23,34]$. In the upper layers of the earth's crust deep methane can be oxidized by reaction:

$$
\mathrm{CH}_{4}+2 \mathrm{H}_{2} \mathrm{O} \leftrightarrow \mathrm{CO}_{2}+4 \mathrm{H}_{2}
$$

In the future, as a result of the dissolution of carbon dioxide in water, sometimes deep hydro carbonate sodium water may be formed.

Carbon dioxide from deep horizons of the earth's crust comes in fault zones that control both hydrothermal fields and hydrocarbon generation zones. Here, on the sites of discharge of fluid streams, there is a selection of $\mathrm{CO}_{2}$ and $\mathrm{CH}_{4}$ (both in free and soluble forms) with a relatively high content of heavy nuclide $\delta^{13} \mathrm{C}[20,25]$. As an example, Druzhkivsky-Konstantinovsky ore field, which is confined to the eponymous anticlinal folds (Table $1)$.

Isotope composition of carbon in waters and gas streams of Druzhkivsky-Konstantinovsky anticline (according to O. Friedman, 1971)

\begin{tabular}{|c|c|c|c|c|c|}
\hline \multirow{2}{*}{$\begin{array}{l}\text { Selection point } \\
\text { sample (well) }\end{array}$} & \multirow{2}{*}{ Phase state } & \multicolumn{2}{|c|}{ Volume share, $\%$} & \multicolumn{2}{|c|}{$\delta^{13} \mathrm{C}, \% o$} \\
\hline & & $\mathrm{CH}_{4}$ & $\mathrm{CO}_{2}$ & $\mathrm{CH}_{4}$ & $\mathrm{CO}_{2}$ \\
\hline \multirow{2}{*}{ № 6-Д } & \multirow{2}{*}{ Gas dissolved in water } & 18,78 & 9,9 & $-20,1$ & $-5,0$ \\
\hline & & 77,1 & 0,5 & - & $-8,1$ \\
\hline № 7-Д & Free gas & 44,8 & 15,3 & & $-15,1$ \\
\hline № 9-Д & Gas dissolved in water & 38,0 & 11,1 & $-30,8$ & $-8,4$ \\
\hline
\end{tabular}

As can be seen from Table 1, heavy isotope of carbon content $\left(\delta^{13} \mathrm{C}\right)$ is greater in carbon dioxide than in methane, which is determined by the thermodynamic properties of carbon in these compounds [28]. The values of $\delta^{13} \mathrm{C}$ for methane vary from $-20,1$ to $-30,8 \%$, indicating its predominantly crust (metamorphogenic-catagenetic) origin [1]. In carbon dioxide, dissolved in pressure sodium chloride and hydro carbonate (chloride) sodium waters and brines, as well as in free $\mathrm{CH}_{4}$ from gas jets, this val- 
ue ranges from 5 to $15,1 \%$, which is more characteristic of its endogenous variety $[15,16,40]$. In our opinion, this is evidenced by the fact that, within hydrothermal hydrocarbon systems, two the most important components - methane and carbon dioxide - can accumulate as a result of endogenous degassing of the Earth $[20,23]$.

Degasification of the mantle in the DnieperDonetsk paleorift is accompanied by the constant emission of fluids, which migrate in sedimentary rocks, "steaming" and saturating them with endogenous components. By deep water moving the processes of catagenetic transformations in the earth's crust can be explained. Deep water absorbs endogenous heat flow and is constantly heated, and while moving to the surface, on the contrary, they give their thermal energy to colder sediment and infiltration water. Thus, it turns out that the spatial coincidence in the region of areas of increased tension of geothermal field with sections of hydrogeothermal mineralization and hydrocarbon accumulations and their ore water can be justified by genetic factors $[2,4,20]$.

Vertical crust-mantle convection, which increases at the moments of folding phases and fades in the periods of relative tectonic stabilization, still continues in the region in accordance with the "posthydrothermal stage" of its geological development [10]. Therefore, within the stable hydrothermal systems limits on the sites of fracture structures with the greatest fluid permeability the long-lived centers of heat transfer have formed. During the long history of geological development of the region there was a periodic discharge of the heat flow in them, hydrothermal solutions and hydrocarbon fluids, which moved to the upper horizons of the earth's crust with the participation of deep formation water, forming bitumen-hydrothermal mineral associations, as well as affecting the formation of ore water [16].

Ancient fluids from which minerals are formed, as well as modern water-gas mixtures discharged into neotectonically activated faults, are part of the halo waters and have sodium chloride or chloridesulfate sodium composition. Sometimes (Slavic brachianthicline) in the liquid phase of hydrothermal inclusions, there are hypogeneous microelements (lithium, cesium, rubidium, mercury, etc.) that are contained in the fluids, unloaded in faults in modern times. The composition of their gas phase (which is dominated by $\mathrm{CH}_{4}, \mathrm{CO}_{2}$ in the presence of $\mathrm{N}_{2}, \mathrm{H}_{2} \mathrm{~S}$, $\mathrm{He}, \mathrm{H}_{2}$, Ar and others, in general corresponds to the composition of gas jets emitted from the fountain wells that revealed the hydrothermal systems of the Bakhmut and Kalmius-Toreka basins (Table 2) $[8,16,25,27]$.

More specific information on the genesis of groundwater of fault structures give, in our opinion, the ratio of concentrations of rare alkalis - lithium, rubidium, and cesium in them. The content of these chemical elements is not controlled by the physical and chemical equilibrium between water and minerals, which confirms them entering the groundwater from the cells of deep generation, therefore, ore and deep waters containing rare alkenes, receive an endogenous component $[1,38]$.

Table 2

Chemical composition of gas-liquid inclusions in hydrothermal minerals from the Slavic brachianthicline

\begin{tabular}{|c|c|c|c|}
\hline \multirow[b]{2}{*}{$\begin{array}{c}\text { Type of } \\
\text { mineralization }\end{array}$} & \multicolumn{2}{|c|}{ Chemical composition } & \multirow{2}{*}{$\begin{array}{c}\text { Literary } \\
\text { source }\end{array}$} \\
\hline & $\begin{array}{c}\text { of gas phase, } \\
\%\end{array}$ & $\begin{array}{l}\text { of liquid phase (water type, } \mathrm{pH} \text {, } \\
\text { mineralization, microelements) }\end{array}$ & \\
\hline Mercury polymetallic & $\begin{array}{c}\mathrm{C}_{2}-44-57 \\
\mathrm{CH}_{4}-10-55 \\
\mathrm{~N}_{2}-8-10, \\
\mathrm{H}_{2}, \mathrm{H}_{2} \mathrm{~S}, \mathrm{C}_{2} \mathrm{H}_{6}, \mathrm{C}_{3} \mathrm{H}\end{array}$ & $\begin{array}{c}\text { Chloride-sodium (calcic) } \\
\mathrm{pH}-6,5-8,5 \\
\text { mineralization }-176 \mathrm{~g} / \mathrm{dm}^{3}\end{array}$ & {$[11]$} \\
\hline
\end{tabular}

Two of the simplest and at the same time informative methods for determining the genesis of solutions are methods based on the ratios of concentrations of lithium, rubidium and cesium, used by different researchers $[1,25,40]$.

On the basis of research results of the content of rare alkalis in the thermal waters of young volcanic areas and fault zones, it was found that lithium, rubidium, cesium, and chlorine could not accumulate in the groundwater due to erosion from rocks, but came from endogenous, possibly mantle cells of generation. To determine the genesis of solutions, it was proposed to use the ratio of the concentrations of rare alkalis: a) for sea water - the content $\mathrm{Li}: \mathrm{Rb}: \mathrm{Cs}=$ 100:78:0,22;

б) for deep (volcanogenic) water the content $\mathrm{Li}: \mathrm{Rb}: \mathrm{Cs}=100: 13: 14$ (100:9:6) [1].

Concentrations of rare alkalis in the water of deep faults, which are discharged within certain hydrothermal-gas structures of the Western-Donetsk graben, indicate that the ore waters of the ore fields is close by composition to modern volcanic waters, and therefore have an endogenous component $[14,22,25,29,30]$.

An important diagnostic feature of determining the genesis of water is also the content of helium, in the composition of deep fluids, unloaded in many 
The ratio of concentrations of lithium, rubidium and cesium in ore waters of fault zones

in some hydrothermal-gas-bearing structures of the region (by V. Suyarko, 2006)

\begin{tabular}{|c|c|c|c|}
\hline $\begin{array}{l}\text { Location and depth of sampling, aquifer } \\
\text { (complex) }\end{array}$ & $\begin{array}{c}\text { concentration in } \\
\text { water, } \\
\mathrm{mg} / \mathrm{dm}^{3}\end{array}$ & $\begin{array}{c}\text { Concentration ratio } \\
\text { Li:Rb:Cs }\end{array}$ & $\begin{array}{l}\text { Genetic type of } \\
\text { groundwater }\end{array}$ \\
\hline $\begin{array}{l}\text { Druzhkivsko-Kostyatinovsky anticline, } \\
\text { well } 7\left(\mathrm{C}_{2}{ }^{3}\right)\end{array}$ & $\begin{array}{l}\mathrm{Li}-0,06 \\
\mathrm{Rb}-0,007 \\
\mathrm{Cs}-0,016\end{array}$ & $100: 11: 26$ & depth water \\
\hline $\begin{array}{l}\text { Slavic dome (Adamivskyi steak), well with } \\
\text { arbitrary outflow }\end{array}$ & $\begin{array}{l}\mathrm{Li}-0,078 \\
\mathrm{Rb}-0,012 \\
\mathrm{Cs}-0,016\end{array}$ & $100: 15: 20$ & depth water \\
\hline
\end{tabular}

deep faults in the region. Its abnormal concentrations (up to $0,067 \%$ ) were detected in gas jets, spontaneously released along with the deep waters in faults, which erode Druzhkivsko-Kostyatinovsky anticline [16]. Helium also occurs on other dome structures of the region with similar geochemical specialization (Krasnopopovskaya, Slavyanskaya, Chervonokiskaya, etc.). In almost all cases, the ratio of nuclides ${ }^{3} \mathrm{He} /{ }^{4} \mathrm{He}$ fluctuates within the limits of $\mathrm{n}$ $10^{-6}-\mathrm{n} 10^{-5}$, which definitely indicates the mantle origin of the element $[25,40]$.

Thus, on the basis of the above signs it can be concluded that the bitumen-hydrothermal mineral associations and the ore waters of the ore fields of the region are formed with the participation of mantle and metamorphogenic fluids, in which some of the main components are carbon and hydrogen.

Conclusions. The results of the study, based on the actual material of field and laboratory works, let us make important conclusions.

1. In Western Donetsk graben, which is an integral part of the Dnieper-Donetsk paleorift, the natural affinity of natural, mostly solid, bitumen to the sections of hydrothermal mineralization in rocks is established. These areas are found in the rocks of the anticlinal structures controlled by the zones of deep faults and their apophyses.
2. The energy sources of the formation of hydrothermal mineralization and natural bitumen are the processes of heat-and-mass transfer, occurring in zones of fluid-dynamically open faults. The upcoming discharge of fluid flows is determined by three most important factors:

a) features of the geological development of the region;

b) its structure;

c) modern level of its tectonic activity.

3. The isotopic composition of the carbon of bitumen indicates that they are, in part, of inorganic origin and were formed as a result of synthesis reactions in thermodynamic conditions of great depths.

This, in turn, does not exclude their income from common with hydrothermal ore-forming fluids generation sources.

4. In the halo waters of the bitumenhydrothermal mineral associations of the region, there are chemical elements and gases that have a deep (mantle) origin. This, as well as the nature of the quantitative ratios of rare alkalis in them, indicates that hydrothermal systems of the ore fields of the Western Donetsk graben are active and are at the modern post-hydrothermal stage of their development.

\section{Jimepamypa}

1. Арсанова, Г. И. Редкие щелочи в термальных водах вулканических областей / Г. И. Арсанова. - Новосибирск : Наука, 1974. - $111 \mathrm{c}$.

2. Багрий, И. Д. Гидро- геосинергетическая биогенно-мантийная гипотеза образования углеводородов и её роль при обосновании прямопоисковой технологии / И. Д. Багрий // Геологический журнал. - 2016. - №2. C. 107-132.

3. Безрук, К. О. Геохімія ртуті у підземних водах геологічних структур Донецькоӥ складчастої структури / К. О. Безрук, Г. В. Лисиченко, В. Г. Суярко. - Київ : ІГНС НАНА Украӥни та ХНУ імені В.Н. Каразіна, 2013. $132 \mathrm{c.}$

4. Белоконь, В. Г. Бассейн р. Сев. Донец как геодинамическая система, отражающая проиессы больших глубин / В. Г. Белоконь. // Геологический журнал. - 1984. - №1. - С. 1-13.

5. Бескровный, Н. С. Нефтеметаллогения: единство нефти и рудообразования / Н. С. Бескровный // Журнал Всесоюзного химического общества имени Д. И. Менделеева. - 1986. - №5. - С. 569-574.

6. Бескровный, Н. С. Нефтянные битумы как спутники гидротермальной деятельности / Н. С. Бескровный. Ленинград : Недра, 1967. - 209 с.

7. Ветштейн, В. Е. Изотопный состав водорода и кислорода вод в зонах глубинных разломов / В. Е.Ветштейн, В. К. Гавриш, Л. К. Гуцุало // Сов. Геология. - 1979. - №7. - С. 96-103. 
8. Возняк, Д. К. Мікровключення та реконструкція умов ендогенного мінералоутворення/ Д.К. Возняк. - К. : Наукова думка, 2007. - 279 с.

9. Гаврилюк, О. В. Палеогидрогеохимические особенности накопления брома в юго-восточной части Днепровско-Донецкой впадины/ О. В. Гаврилюк // Вісника Одеського начіонального університету. Серія: «Географічні та геологічні науки». - 2015. - Т. 20, вип. 3. - С. 145-153.

10. Гавриш, В. К. Ртутно-вуглеводнева зональність Доно-Дніпровського прогину / В. К. Гавриш, Л. А. Добрянський, М. В. Курило. // ДАН УССР. - 1984. - №7. - С. 18-21.

11. Генетические особенности минералообразования Славянского ртутного месторождения / Б. В.Заџиха, О. И. Петриченко, Б. В. Долишний, В. А. Ласьков // Минералогический сборник Львовского университета. 1973. - №27. - C. 326-332.

12. Добрянский, Л. А. Парагенезис ртути и углеводородов - важное направление геологических исследований Л. А. Добрянский, В. К. Гавриш. // Геологический журнал. - 1988. - №48. - С. 3-11.

13. Іщенко, Л. В. Геохімічні критерї пошуків вуглеводнів на сході Дніпровсько-Донецької западини / Л. В. Іщченко. // Вісник ХНУ імені В.Н.Каразіна. - 2015. - №48. - С. 88-93.

14. Іщенко, Л. В. Закономірності розміщення покладів вуглеводнів та зон гідротермальної мінералізації на території східної частини Донецької складчастої споруди / Л. В. Іщенко // Вісник ХНУ імені В.Н. Каразіна. 2016. - №45. - C. 38-42.

15. Іщенко, Л. В. Умови формування бітумо-гідротермальних асоиіацій в антиклінальних структурах ЗахідноДонецького грабену / Л. В. Іщенко // Міжнародна наукова конференція «Геологія і геохімія горючих копалин», присвяченої 100-річчю від дня народження академіка Г. Н. Доленка. - 2017. - С. 69-71.

16. Кирикилица, С. И. О составе и природе свободных газовыделений (газовых струй) ртутных рудопроявлений Дружковско-Костантиновской антиклинали / С. И. Кирикилица, М. Л. Левенштейн, А. И. Фридман // Геологический журнал. - 1972. - №2. - С. 92-97.

17. Кононов, В. И. Геохимия термальных вод современного вулканизма (рифтовых зон и островных дуг) / В. И. Кононов. - Москва : Наука, 1983. - 216 с.

18. Лялько, В. И. Тепломасоперенос в литосфере / В. И. Лялько. - Киев,: Наукова думка, 1985. - 259 c.

19. Лукин, А. Е. О роли глубинных и сверхглубинных флюидов в процессах нефтегазообразования / А. Е. Лукин, Ю. И. Пиковский // Геологічний журнал. - 2004. - №2. - С. 21-33.

20. Лукин, А. Е. О сквозьформаччионных флюидопроводящих системах в нефтегазоносных бассейнах / A. E. Лукин // Геологический журнал. - 2004. - №3. - С. 34-45.

21. Масленников, В. В. Сходство условий формирования нефтянных газовых и ртутных месторождений / В. В. Масленников. - 1987. - №10. - C. 108-114.

22. Нант, Д. Е. О вероятном рудообразующем магматическом растворе и метаморфизирующчихся породах, вскрытых глубокой скважиной в Южной Калифорнии / Д. Е. Нант, Е. Т. Андерсон, Д. Е. Груббс // Геохимия современных поствулканических прочессов. - М. : Мир, 1965. - С. 167-171.

23. Панов, Б. С. Изотопный состав кислорода и углерода карбонатов Донбасса / Б. С. Панов, В. А. Корчемагин, И. К. Пилот // ДАН УССР. - 1974. - №3. - С. 226-234.

24. Стебельська, Г. Я. Новий погляд на проблему класифікачії нафт / Г. Я. Стебельська // Вісник ХНУ імені В.Н.Каразіна. - 2017. - №46. - С. 50-56.

25. Стебельська, Г. Я. Закономірності розміщення покладів природних бітумів / Г. Я. Стебельська. // Геологія $i$ геохімія горючих копалин. - 2017. - №1. - С. 168-169.

26. Суярко. В. Г. Геохимия подземных вод / В. Г. Суярко. - Харьков, 2006. - 296 с.

27. Суярко. В. Г. Гидрогеохимические особенности и поисковые критерии ртутных месторождений Донбасса / В. Г. Суярко // Геол.журнал. - 1981. - №2. - С. 147-149.

28. Суярко, В. Г. Структурно-геохімічні критерї прогнозування скупчень вуглеводнів (на прикладі ЗахідноДонецького грабену) / В. М. Загнітко, Г. В. Лисиченко // Київ : Салютіс, 2010. - С. 83.

29. Суярко, В. Г. Про джерела надходження та міграцію брому в підземних водах ( на прикладі ДніпровськоДонецького авлакогену) / В. Г. Суярко, О.В. Гаврилюк // Вісник Харківського національного університету імені В.Н. Каразіна. Серія:«Геологія. Географія. Екологія». - 2014. - №41 (1128). - С. 70-75.

30. Суярко, В. Г. Геохімічні особливості ореольних вод основних типів гідротермального зруденіння Донецької складчастої споруди / В. Г. Суярко, Л. В. Іщенко, О. О. Сердюкова // Пошукова та екологічна геохімія. 2017. - №1. - C. 44-51.

31. Термодинамическая модель системы C-H в условиях высоких температур и давлений / В. С. Зубков, А. Н. Степанов, И. К. Карпов, В. А. Бычинский // Геохимия. - 1998. - №1. - С. 95-101

32. Уайт, Э. Д. Месторождения ртути и цвветных металлов, связанные с термальными минеральными источниками /Э. Д. Уайт // Геохимия рудных месторождений. - Москва : Мир, 1970. - С. 479-524.

33. Чекалюк, Э. Б. Термодинамические основы минерального происхождения нефти / Э. Б. Чекалюк. - Киев : Наукова думка, 1971. - 265 c.

34. Хоха, Ю. В. Термодинаміка глибинних вуглеводнів у прогнозуванні регіональної газоносності / Ю. В. Хоха. Киів : Наукова думка, 2014. - 56 c.

35. Шумлянский, В. А. Киммерийская металлогеническая эпоха на территории Украины / В.А. Шумлянский. Киев, 1983.

36. James, A. N. Tow metallogenesic maps for North America / Noble James. // Geol. Rundshall. - 1980. - №69. - C. 594-608. 
37. Giardini, A. A. Evidence that stable carbon isotops are not a reliable criterion for distinguishing biogenetic from non-biogenic petroleum / A. A. Giardini, C. E. Melton. // L. Petrol. Geol. - 1982. - №4. - C. 437-439.

38. Ellis, A. I. Natural hydrothermal sestems and experimental hot water/ roch interaction / A. I. Ellis, W. A. Mahon // Geohim. et Cosmochim. Acta. - 1964. - №28. - P. 1323-1357.

39. Tracing helium isotope compositions from mantle source to fumaroles at Oldoinyo Lengai volcano, Tanzania / [G. Mollex, E. Furi, P. Burnard ma iн.]. // Chemical Geology. - 2018. - №480. - P. 66-74.

40. White, D. E. Magmatic, connate and metarmorphic water // Bull. Geol.Soc.Amer. - 1957. - №12. - P. $1659-1682$.

UDC 556.314:550.4

Vasyl Suyarko,

Doctor of Science (Geology and Mineralogy), Professor,

Chair of Mineralogy, Petrography and Minerals, V. N.Karazin Kharkiv National University, Svobody sq., 4, Kharkiv, 61022, Ukraine,

e-mail: vgsuyarko@gmail.com, https://orcid.org/0000-0002-3693-4767;

\section{Liliya Ishchenko,}

$\mathrm{PhD}$ student, Lecturer,

Chair of Mineralogy, Petrography and Minerals, V.N.Karazin Kharkiv National University, lvishchenko23@gmail.com, https://orcid.org/0000-0002-0848-368X;

Olga Gavrilyuk,

PhD student, Lecturer,

Department of Soil Mechanics, Foundations and Engineering Geology,

O. M. Beketov National University of Urban Economy in Kharkiv, e-mail: gavrilyk.o.v@gmail.com, https://orcid.org/0000-0002-7057-2499

\section{FLUID REGIME AND ORE WATER OF BITUMO-HYDROTHERMAL MINERAL ASSOCIATIONS IN THE CONDITIONS OF WESTERN DONETSK GRABEN}

The fluid regime of bitumen-hydrothermal mineral associations on the ore fields of the Western Donetsk graben, which are part of the Dnieper-Donetsk paleorift, has certain geochemical features. It is conditioned by the peculiarities of geological development, structure and the current level of tectonic activity of the region.

The purpose of the article is to study the fluid regime of bitumen-hydrothermal mineral associations and the participation of hydrocarbons in the hydrothermal process.

The research methodology consisted of a theoretical interpretation of laboratory studies, in particular chemical analyzes of rocks, ore minerals, bitumen, groundwater and gases, as well as isotopic analysis of carbon of solid bitumen.

Research results. Field studies have found that bitumen-hydrothermal mineralization in the rocks is naturally timed to tectonically activate anticlinal structures.

The energy source of its formation are the polychronous processes of heat-and-mass transfer, the power of which is determined by the tectonic activity of the zones of deep faults. In the rocks of the region, with the specified type of ore mineralization (mercury and mercury-polymetallic), the halo waters of a certain geochemical specialization are formed, which include chemical elements of ore and impure minerals and bitumen, as well as endogenous fluids. Among such fluids is the carbon of solid hydrocarbon compounds, the isotopic composition of which indicates its inorganic origin.

The presence of bitumen-hydrothermal mineral associations of chemical elements and gases in halo waters of deep origin indicates that hydrothermal systems of the ore fields of the Western Donetsk graben are on the modern, post-hydrothermal stage of development.

The scientific novelty of the material presented in the article is based on several substantive theoretical conclusions, which are based on the actual material of the research carried out by the authors.

The natural affinity of bitumen-hydrothermal associations to tectonically activate structures located in the zones of deep faults has been proved.

The affinity of inorganic carbon bitumino-hydrothermal mineral associations in solid bitumen and chemical elements present in gas jets and groundwater to metamorphic and mantle processes $\left(\mathrm{He}, \mathrm{H}_{2}, \mathrm{Hg}\right.$, $\mathrm{CO}_{2}, \mathrm{CH}_{4}, \mathrm{Li}, \mathrm{Rb}, \mathrm{Cs}$, etc.) is substantiated., which are manifestations of modern tectonic activity of alpine tectogenesis.

It was substantiated that the formation of the chemical composition of the halo waters of bitumen- 
hydrothermal mineral associations is provided both by exchange chemical processes in the system "mineralwater-gas" and by the income of fluids of deep genesis.

The practical significance of the work is conditioned, on the one hand, by the use of ore hydrothermal mineralization in the rocks as a criterion for the search of hydrocarbon accumulations, and on the other hand, by the prediction of the possibility of hydrocarbon compounds upcoming from large depths in which, in abnormal thermodynamic conditions, an inorganic synthesis of hydrocarbons takes place.

Keywords: fluid regime, bitumen-hydrothermal association, Western Donetsk graben, tectonic fault, heat-and-mass transfer, halo water, gases, chemical elements, tectonic phase.

\section{References}

1. Arsanova, G. I. (1974). Rare alkali in the thermal waters of volcanic areas. Nauka, 111 .

2. Bagrij, I. D. (2016). Water-based hydro-geosynergetic biogenic-mantle hypothesis of hydrocarbon formation and its role in substantiation of search technology. Geologicheskij zhurnal, 2, 107-132.

3. Bezruk, K. O., Lisichenko, G. V., Suyarko, V. G. (2013). Geochemistry of mercury in underground waters of geological structures of Donetsk folded structure. Kyiv: IGNS of the National Academy of Sciences of Ukraine and KhNU named after VN Karazin, 132.

4. Belokon', V. G. (1984). Bassejn r. Seversky Donets as a geodynamic system that reflects the processes of great depths. Geologicheskij zhurnal, 1, 1-13.

5. Beskrovnyj, N. S. (1986). Petroleum formation: unity of oil and ore formation. Zhurnal Vsesojuznogo himicheskogo obshhestva imeni D. I. Mendeleeva, 5, 569-574.

6. Bondarenko, G. N. (1983) Formation of the isotope composition of the carbonate system of natural waters. Nauk.dumka, 152.

7. Vetshtejn, V.E., Gavrish, V. K., Gucalo, L. K. (1979). Isotope composition of hydrogen and oxygen of waters in deep fault zones. Sov. Geologija, 7, 96-103.

8. Voznyak, D. K.( 2007) Microinclusion and recon struction of the endogenous mineralization conditions. Naukova dumka,279.

9. Gavriljuk, O. V. (2015). Paleohydrogeochemical features of bromine accumulation in the south-eastern part of the Dnipro-Donets valley. Serija: "Geografichni ta geologichni nauki», 20 (3), 145-153.

10. Gavrish, V. K., Dobryansky, L. A., Kuril, M. V. (1984) Mercury-hydrocarbon zoning of the Don-Dniprovsky trough DAN USSR, 7, 18-21.

11.Zaciha, B. V., Petrichenko, O. I., Dolishnij, B. V., Las'kov, V. A. (1973). Origin of mineral formation of the Slavic mercury deposit. Mineralogicheskij sbornik L'vovskogo universiteta, 27, 326-332.

12. Dobryansky, L. A., Gavrish, V. K. (1988). Paragenesis of mercury and hydrocarbons - an important direction of geological research. Geological Journal, 48, 3-11.

13. Ishhenko, L. V. (2015). Geochemical criteria for the search of hydrocarbons in the east of the Dnipro-Donets depression. Visny`k XNU imeni V.N.Karazina, 48, 88-93.

14. Ishhenko L. V. (2016). Patterns of placement of hydrocarbon deposits and zones of hydrothermal mineralization in the territory of the eastern part of the Donetsk folded structure.Visny`k XNU imeni V. N. Karazina, 45, 38-42.

15. Ishhenko, L. V. (2017). Conditions for the formation of bitumen-hydrothermal associations in the anti-clannic structures of the West-Donetsk graben. Mizhnarodna naukova konferenciya "Geologiya i geoximiya goryuchy`x kopaly 'n», pry`svyachenoyi 100-richchyu vid dnya narodzhennya akademika G. N. Dolenka, 69-71.

16. Kirikilica, S. I., Levenshtejn, M. L., Fridman, A. I. (1972). On the composition and nature of free gas emissions (gas jets) of mercury ore occurrences in the Druzhkov-Kostantinovskaya anticline. Geologicheskij zhurnal, 2, 92-97.

17. Kononov, V. I. (1983). Geochemistry of thermal waters of modern volcanism (rift zones and island arcs). Nauka, 216.

18. Ljal'ko, V. I. (1985). Heat and mass transfer in the lithosphere. Naukova dumka,259.

19. Lukin A. E. (2004). On the formation of fluid-conducting fluid systems in oil and gas basins. Geologicheskij zhurnal, $3,34-45$.

20. Lukin, A. E., Pikovskii, Yu. I. (2004). On the role of deep and super deep fluids in the processes of oil and gas formation. Geological Journal,2, 21-33.

21. Maslennikov, V.V. (1987). The similarity of the conditions for the formation of oil gas and mercury deposits, 10, 108114.

22. Nant, D. E., Anderson, E. T., Grubbs, D. E. (1965). On the probable ore-forming magmatic solution and metamorphosed rocks discovered by a deep well in Southern California. Geohimija sovremennyh postvulkanicheskih processov. Moscow, Russia: Mir,167-171.

23. Panov, B. S., Korchemagin, V. A., Pilot, I. K. (1974). Isotope composition of oxygen and carbon of Donbas carbonates. DAN USSR, 3, 226-234.

24. Stebelskaya, G. Ya. A (2017). New View on the Problem of the Classification of Oil. The Bulletin of the VN Karazin $K h N U, 46,50-56$.

25. Stebelskaya, G. Ya. (2017). Regularities of placement of natural bitumen deposits. Geology and Geochemistry of Combustible Minerals, 1, 168-169.

26. Suyarko, V. G. (2006). Geochemistry of groundwater. Kharkov, KhNU named after VN Karazin,296. 
27. Suyarko, V. G. (1981). Hydrogeochemical features and search criteria for mercury deposits in Donbas. Geological Journal, 2, 147-149.

28. Suyarko, V.G., Zagnitko, V. M., Lisychenko, G. V. (2010). Structural-geochemical criteria of forecasting of hydrocarbon accumulations (on the example of West-Donetsk graben). Kiev: Salyutis, 83.

29. Suyarko, V.G., Gavryliuk, O. V. (2014). On sources and bromine migration in underground waters (on the example of Dnieper-Donetsk aulacogen). The Bulletin of the Kharkiv National University named after VN Karazin Series: "Geology. Geography. Ecology", 41 (1128), 70-75.

30. Suyarko, V. G., Ishchenko, L.V., Serdyukova, O.O. (2017). Geochemical features of the hay water of the main types of hydrothermal mineralization of the Donetsk folded structure. Search and ecological geochemistry, 1, 44-51.

31.Zubkov, V. S., Stepanov, A. N., Karpov, I. K., Bychinsky, V. A. (1998). Thermodynamic model of the CH system under conditions of high temperatures and pressures. Geochemistry, 1, 95-101.

32. White, E. D. (1970). Deposits of mercury and non-ferrous metals associated with thermal mineral springs. Geochemistry of Ore Deposits. Moscow: The World, 479-524.

33. Chekalyuk, E. B. (1971). Thermodynamic foundations of mineral origin of oil. Kiev: Naukova Dumka,265.

34. Khokha, Yu. V. 2014Thermodynamics of deep hydrocarbons in forecasting of regional gas content. Kyyv: Naukova dumka, 56.

35. Shumlyansky, V. A. (1983). Cimmerian metallogenic epoch on the territory of Ukraine. Kyyv, 234.

36. James, A. N. (1980). Tow metallogenesic maps for North America. Geol. Rundshall, 69, 594-608.

37. Giardini, A. A., Melton, C. E. (1982). Evidence that stable carbon isotops are not a reliable criterion for distinguishing biogenetic from non-biogenic petroleum. Petrol. Geol., 4, 437-439.

38. Ellis, A. I., Mahon, W. A. (1964). Natural hydrothermal sestems and experimental hot water. Geohim. et Cosmochim. Acta, 8, 1323-1357.

39. Mollex, G., Furi, E., Burnard, P. (2018). Tracing helium isotope compositions from mantle source to fumaroles at Oldoinyo Lengai volcano, Tanzania. Chemical Geology, 480, 66-74.

40. White, D. E. (1957). Magmatic, connate and metarmorphic water. Bull. Geol.Soc.Amer, 12, 1659-1682. 